\section{Story of human connection}

\author{
Adaira Landry ำ , Kei Ouchi
}

My patient was old and tired. And he was beginning to struggle to breathe.

"Sir," I said, "I'd like to record a message of you on my phone. I want to send it to your children."

I spoke gently, aiming for grace and patience as I stood at the foot of his bed. Had circumstances been normal, I would not have made this request. I would not have needed to. This man would have had his family gathered around his bedside to comfort him. But my patient had arrived as coronavirus was sweeping across the country, an illness which, in addition to causing rapid deterioration of many, manages to rob us of the most basic forms of human connection we rely so heavily on in moments of upheaval.

I did not relish asking a sick patient to let me film him, but this was my best chance at connecting my patient, in these critical moments, to his loved ones. He was still coherent and able to consent, though that would not remain the case for much longer. The end of this man's life was approaching. The weight of this personal moment was apparent and shared only between us, a doctor and a patient. I thought his family should be involved, too. He breathed out the word, 'Okay', barely audible over the oxygen filling his mask.

There in the hospital, he gave me, a masked doctor, his entire trust. I was frank with him, letting him know that this would be the message his children would watch when they missed him. In contrast to his previous whisper, he used his remaining strength to project and speak with clarity. "The best day of my life was the day each of you was born. I love you all so much. I love you.” That was all he said, those three sentences.

Before arriving at the ED, my patient had been living in a nursing home, where he had been alone. His children had not been able to see him for 6 weeks due to visitation restrictions and had not been able to hear his voice for 2 weeks because his phone had stopped working. When he had first arrived in the hospital, we attempted a few video calls with his daughter, but they were overwhelming for him. "Please keep him comfortable, and do nothing invasive

Department of Emergency Medicine, Brigham and Women's Hospital, Boston, Massachusetts, USA

Correspondence to Dr Adaira Landry, Department of Emergency Medicine, Brigham and Women's Hospital, Boston, MA 02130, USA; ailandry@bwh.harvard.edu or painful," she said. After one call with his daughter, when it was just my patient and me in the room, he was able to focus and speak sincerely about his family. So I did something I had never done before. I recorded a message of my dying patient on my phone, an effort to offer some consolation under new and heartbreaking circumstances in which connection is scarce.

The best practice of medicine occurs when we solve problems through human connection. In the ED, we specialise in establishing these bonds with speed and humility. Even in the toughest of situations - a patient dying unexpectedly-we bring family members to the bedside to participate in a familywitnessed resuscitation. It might sound gruesome to welcome a relative or friend to these significant events, but death is a natural process. It is an expansive experience, full of emotions that push and pull us, ones we simply have to allow ourselves to be carried on like a tide. Offering family members the opportunity to connect with and be present for their dying loved ones helps us all. Together, we are able to see how meaningful the death is to each of us as it occurs. Together, we process the profound experience, letting it wash over us like waves on a beach. Back and forth, crashing or silent.

Emergency physicians take pride in providing humanity within the hospital. Before a critical procedure when the outcome could be grim, such as an emergency intubation, we encourage loved ones to speak with patients. We welcome words, touch, silence, laughter and crying into our medical practice. These gifts help physicians, families, friends and the patient. This connection helps us to stay present. And this presence helps us to grieve, to cope and eventually, to heal.

In the wake of COVID-19, these shared moments that once brought great comfort to the hospital experience are absent. Patients are dying alone. Loved ones are left with few opportunities to interact. Physicians and nurses enter the room sparingly, often only when absolutely necessary. We have become physically distanced out of necessity, and we are each suffering alone. We are a social species, and medicine is a social field. But doctoring in medicine is not only the act of performing complicated procedures or diagnosing rare diseases. Doctoring, now more than ever before, is finding which hard moments we can soften with our presence.
Practising medicine in the ED during this pandemic is a privilege. As physicians, we are allowed to recognise that honour and fear can coexist. We are able to find meaning in supporting patients, both living and dying, in a world full of anxiety. And we can provide care and comfort. In a time of great isolation, we can make whatever efforts we can to keep families involved in the care of patients, connecting them via phone and app-based video calls.

It was this desire-to provide connection in a deeply difficult time-that drove me to capture and preserve my patient's final conscious moments. It was a small act. But I did not want these intensely emotional moments and thoughts to belong only to me. I wanted to offer them to his loved ones, as well.

I sent the video to his daughter.

We later escorted the patient upstairs to his room, aware that he would die from this infection, as have nearly 70000 other Americans as of this writing. We were lucky. His death was not without company; our team had connected with him at his bedside. His death was not without record, as his experience has now been shared.

Contributors Both authors of this manuscript contributed substantially to the creation of this document.

Funding The authors have not declared a specific grant for this research from any funding agency in the public, commercial or not-for-profit sectors.

\section{Competing interests None declared.}

Patient and public involvement Patients and/or the public were not involved in the design, or conduct, or reporting, or dissemination plans of this research.

Patient consent for publication Not required.

Provenance and peer review Not commissioned; internally peer reviewed.

This article is made freely available for use in accordance with BMJ's website terms and conditions for the duration of the covid-19 pandemic or until otherwise determined by BMJ. You may use, download and print the article for any lawful, non-commercial purpose (including text and data mining) provided that all copyright notices and trade marks are retained.

(C) Author(s) (or their employer(s)) 2020. No commercial re-use. See rights and permissions. Published by BMJ.

Handling editor Ellen Weber

Check for updates

To cite Landry A, Ouchi K. Emerg Med J 2020;37:526.

Received 8 May 2020

Revised 21 May 2020

Accepted 21 May 2020

Published Online First 12 July 2020

Emerg Med J 2020;37:526.

doi:10.1136/emermed-2020-209987

ORCID iD

Adaira Landry http://orcid.org/0000-0002-5299-679X 